Article

\title{
Isolation and Structure Elucidation of Three New Dolastanes from the Brown Alga Dilophus spiralis
}

\section{Efstathia Ioannou, Constantinos Vagias $^{\dagger}$ and Vassilios Roussis *}

Department of Pharmacognosy and Chemistry of Natural Products, School of Pharmacy, University of Athens, Panepistimiopolis Zografou, Athens 15771, Greece; E-Mail: eioannou@pharm.uoa.gr

$\dagger$ Deceased on 12 May 2010.

* Author to whom correspondence should be addressed; E-Mail: roussis@pharm.uoa.gr; Tel./Fax: +30-210-727-4592.

Received: 25 February 2013; in revised form: 13 March 2013 / Accepted: 19 March 2013 / Published: 2 April 2013

\begin{abstract}
Three new dolastane diterpenes (1-3) and five previously reported perhydroazulenes were isolated from the organic extracts of the brown alga Dilophus spiralis. The structure elucidation and the assignment of the relative configurations of the isolated natural products were based on extensive analyses of their spectroscopic data, whereas the absolute configuration of metabolite $\mathbf{2}$ was determined through its chemical conversion to a previously isolated compound of known configuration.
\end{abstract}

Keywords: Dilophus spiralis; dolastanes; structure elucidation

\section{Introduction}

The family Dictyotaceae comprises cosmopolitan species of brown algae which are considered a prolific source of secondary metabolites. Representatives of the family have been the subject of numerous chemical studies over the last 50 years yielding approximately 500 new natural products. Many of these metabolites have been evaluated for and proven to possess different levels of antibacterial, antiviral, cytotoxic, antifeedant, ichthyotoxic, algicidal, and/or antifouling activities. Among these, species of the genera Dictyota and Dilophus produce mainly sesquiterpenes and diterpenes of normal biosynthesis featuring a wide range of carbon skeletons [1,2].

In the course of our ongoing research focusing on the isolation of bioactive secondary metabolites from marine organisms found along the coastlines of Greece, we initiated a thorough investigation of the 
chemical composition of Dilophus spiralis (Montagne) Hamel (syn. ligulatus). Previously, we described the isolation and structural characterization of five new dolastanes, one new 2,6-cyclo-xenicane, twenty new dolabellanes, two diterpenes featuring novel carbon skeletons, and several known compounds [3-7]. Herein, we report the isolation and structure elucidation of three new dolastanes (1-3) and five known perhydroazulene diterpenes.

\section{Results and Discussion}

A series of chromatographic separations of the organic extracts of the brown alga D. spiralis, collected in Elafonissos island, Greece, resulted in the isolation of the new dolastanes 1-3 (Figure 1) and five previously reported perhydroazulenes, which were identified as dictytriene B [8], dictyoxide [9], pachydictyol A [10], isopachydictyol A [11], and dictyol E [12] by comparison of their spectroscopic and physical characteristics with those reported in the literature.

Figure 1. Chemical structures of compounds 1-3 isolated from Dilophus spiralis.

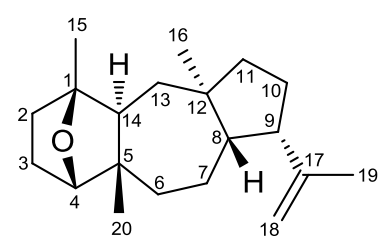

1

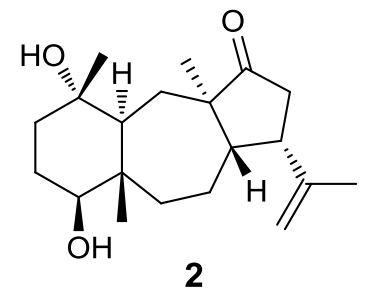

2

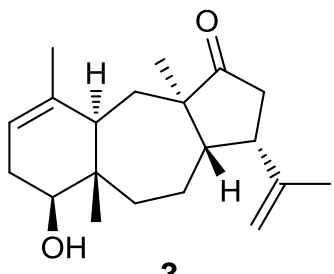

3

Compound 1, isolated as a colorless oil, displayed an ion peak at $\mathrm{m} / \mathrm{z} 288.2459$ (HRFABMS), corresponding to $\mathrm{C}_{20} \mathrm{H}_{32} \mathrm{O}$ and consistent with $[\mathrm{M}]^{+}$. The ${ }^{1} \mathrm{H}$ NMR spectrum (Table 1) included signals for four singlet methyls $\left(\delta_{\mathrm{H}} 0.86,1.13,1.23\right.$, and 1.64), one exomethylene group ( $\delta_{\mathrm{H}} 4.65$ and 4.74$)$, and an oxygenated methine $\left(\delta_{\mathrm{H}} 3.72\right)$. The ${ }^{13} \mathrm{C}$ NMR spectrum (Table 2 ) revealed 20 carbon signals, which corresponded to four quaternary carbon atoms, four methines, eight methylenes, and four methyls, as determined from DEPT experiments. Among them, two olefinic ( $\delta_{\mathrm{C}} 112.8$ and 147.4) and two oxygenated $\left(\delta_{\mathrm{C}} 84.6\right.$ and 85.5$)$ carbons were evident. Since the carbon-carbon double bond accounted for one of the five degrees of unsaturation, the molecular structure of $\mathbf{1}$ was determined as tetracyclic. Due to the presence of two oxygenated carbons but only one oxygen atom in the molecule, in combination with the absence of an absorption band at either $1670-1750$ or $3300-3500 \mathrm{~cm}^{-1}$ in the IR spectrum, the oxygen atom was assigned to an ether function. Comparison of these spectroscopic characteristics to those previously reported for dolastane diterpenes [3] and analysis of the correlations observed in the HMBC and COSY spectra (Figure 2) pointed to a 17-dolastene skeleton. In particular, the presence of the isopropenyl group was indicated by the long-range coupling between $\mathrm{H}_{2}-18$ and $\mathrm{H}_{3}-19$ and the HMBC correlations of C-9 and C-17 with $\mathrm{H}_{2}-18$ and $\mathrm{H}_{3}-19$, whereas the cross-peaks of $\mathrm{H}-8 / \mathrm{H}-9$, $\mathrm{H}-9 / \mathrm{H}_{2}-10$ and $\mathrm{H}_{2}-10 / \mathrm{H}_{2}-11$, in conjunction with the HMBC correlations of C-8, C-11 and C-12 with $\mathrm{H}_{3}-16$ confirmed the assignment of the five-membered ring and placed the first aliphatic methyl on C-12. The COSY correlations of $\mathrm{H}_{2}-6 / \mathrm{H}_{2}-7, \mathrm{H}_{2}-7 / \mathrm{H}-8$ and $\mathrm{H}_{2}-13 / \mathrm{H}-14$, as well as the $\mathrm{HMBC}$ correlations of C-5 and C- 6 with $\mathrm{H}-14$ and $\mathrm{H}_{3}-20$ and of C-13 with $\mathrm{H}_{3}-16$ defined the seven-membered ring and fixed the position of the second aliphatic methyl on $\mathrm{C}-5$. Furthermore, the HMBC correlations of C-1 and C-2 with $\mathrm{H}_{3}-15$, of C-4 with $\mathrm{H}_{3}-20$ and of C-14 with $\mathrm{H}-4$ and $\mathrm{H}_{3}-15$, in combination with the 
cross-peaks of $\mathrm{H}-2 / \mathrm{H}_{2}-3$ and $\mathrm{H}-3 \beta / \mathrm{H}-4$ concluded the assignment of the six-membered ring and placed the third aliphatic methyl on C-1. Finally, the correlation of C-1 with H-4 observed in the HMBC spectrum indicated that the ether bridge was positioned between carbons C-1 and C-4.

Table 1. ${ }^{1} \mathrm{H}$ NMR data (400 MHz, $\mathrm{CDCl}_{3}$ ) of compounds $\mathbf{1}-\mathbf{3}$.

\begin{tabular}{|c|c|c|c|c|c|c|}
\hline Position & & 1 & & 2 & & 3 \\
\hline \multirow[t]{2}{*}{2} & $\mathrm{a}$ & $1.45 \mathrm{~m}$ & $\alpha$ & $1.51 \mathrm{~m}$ & & $5.32 \mathrm{brs}$ \\
\hline & $\mathrm{b}$ & $1.34 \mathrm{~m}$ & $\beta$ & $1.73 \mathrm{~m}$ & & \\
\hline \multirow[t]{2}{*}{3} & $\alpha$ & $1.83 \mathrm{~m}$ & $\alpha$ & $1.71 \mathrm{~m}$ & $\alpha$ & $2.24 \mathrm{~m}$ \\
\hline & $\beta$ & $1.70 \mathrm{~m}$ & $\beta$ & $1.52 \mathrm{~m}$ & $\beta$ & $1.91 \mathrm{~m}$ \\
\hline 4 & & $3.72 \mathrm{~d}(5.8)$ & & $3.19 \mathrm{dd}(10.9,4.0)$ & & $3.42 \mathrm{~m}$ \\
\hline \multirow[t]{2}{*}{6} & $\alpha$ & $1.62 \mathrm{~m}$ & $\alpha$ & $1.27 \mathrm{~m}$ & $\alpha$ & $1.28 \mathrm{~m}$ \\
\hline & $\beta$ & $1.27 \mathrm{~m}$ & $\beta$ & $2.24 \mathrm{dd}(14.6,8.4)$ & $\beta$ & $2.37 \mathrm{dd}(14.8,8.9)$ \\
\hline \multirow[t]{2}{*}{7} & $\mathrm{a}$ & $1.68 \mathrm{~m}$ & $\alpha$ & $1.67 \mathrm{~m}$ & $\alpha$ & $1.77 \mathrm{~m}$ \\
\hline & $\mathrm{b}$ & $1.37 \mathrm{~m}$ & $\beta$ & $1.84 \mathrm{~m}$ & $\beta$ & $1.93 \mathrm{~m}$ \\
\hline 8 & & $2.16 \operatorname{td}(11.5,1.6)$ & & $2.51 \mathrm{dt}(13.8,7.5)$ & & $2.68 \operatorname{ddd}(13.8,7.9,7.5)$ \\
\hline 9 & & $2.86 \mathrm{dt}(11.5,9.1)$ & & 2.77 ddd $(7.8,7.5,2.8)$ & & 2.79 ddd $(8.3,7.9,2.1)$ \\
\hline \multirow[t]{2}{*}{10} & $\mathrm{a}$ & $1.76 \mathrm{~m}$ & $\mathrm{a}$ & $2.62 \mathrm{dd}(19.2,2.8)$ & a & $2.61 \mathrm{dd}(19.2,2.1)$ \\
\hline & $\mathrm{b}$ & $1.67 \mathrm{~m}$ & $\mathrm{~b}$ & $2.56 \mathrm{dd}(19.2,7.8)$ & $\mathrm{b}$ & $2.56 \mathrm{dd}(19.2,8.3)$ \\
\hline \multirow[t]{2}{*}{11} & $\mathrm{a}$ & $1.54 \mathrm{~m}$ & & & & \\
\hline & $\mathrm{b}$ & $1.31 \mathrm{~m}$ & & & & \\
\hline \multirow[t]{2}{*}{13} & $\alpha$ & $1.38 \mathrm{~m}$ & $\alpha$ & $2.13 \mathrm{dd}(13.7,2.8)$ & $\alpha$ & $2.11 \mathrm{~m}$ \\
\hline & $\beta$ & $1.25 \mathrm{~m}$ & $\beta$ & $1.16 \mathrm{~m}$ & $\beta$ & $1.05 \mathrm{t}(14.0)$ \\
\hline 14 & & $1.49 \mathrm{~m}$ & & $1.40 \mathrm{dd}(12.6,2.8)$ & & $2.13 \mathrm{~m}$ \\
\hline 15 & & $1.23 \mathrm{~s}$ & & $1.07 \mathrm{~s}$ & & $1.63 \mathrm{~s}$ \\
\hline 16 & & $0.86 \mathrm{~s}$ & & $1.03 \mathrm{~s}$ & & $1.07 \mathrm{~s}$ \\
\hline \multirow[t]{2}{*}{18} & $\mathrm{a}$ & $4.74 \mathrm{~d}(2.3)$ & $\mathrm{a}$ & $4.96 \mathrm{brs}$ & $\mathrm{a}$ & $4.99 \mathrm{brs}$ \\
\hline & $\mathrm{b}$ & $4.65 \mathrm{~d}(2.3)$ & $\mathrm{b}$ & $4.68 \mathrm{brs}$ & $\mathrm{b}$ & $4.71 \mathrm{brs}$ \\
\hline 19 & & $1.64 \mathrm{~s}$ & & $1.78 \mathrm{~s}$ & & $1.82 \mathrm{~s}$ \\
\hline 20 & & $1.13 \mathrm{~s}$ & & $0.88 \mathrm{~s}$ & & $0.84 \mathrm{~s}$ \\
\hline
\end{tabular}

Figure 2. Key COSY and HMBC correlations observed for compound 1.
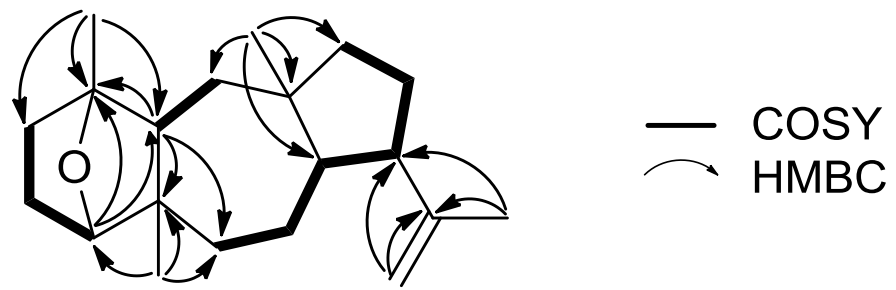
Table 2. ${ }^{13} \mathrm{C}$ NMR data $\left(50 \mathrm{MHz}, \mathrm{CDCl}_{3}\right)$ of compounds $\mathbf{1}-\mathbf{3}$.

\begin{tabular}{ccccccc}
\hline Position & & $\mathbf{1}$ & & & $\mathbf{2}$ & \multicolumn{2}{c}{$\mathbf{3}$} & \\
\hline 1 & 84.6 & $\mathrm{C}$ & 72.3 & $\mathrm{C}$ & 135.6 & $\mathrm{C}$ \\
2 & 41.5 & $\mathrm{CH}_{2}$ & 40.7 & $\mathrm{CH}_{2}$ & 120.4 & $\mathrm{CH}$ \\
3 & 24.5 & $\mathrm{CH}_{2}$ & 28.4 & $\mathrm{CH}_{2}$ & 32.1 & $\mathrm{CH}_{2}$ \\
4 & 85.5 & $\mathrm{CH}$ & 78.2 & $\mathrm{CH}$ & 74.9 & $\mathrm{CH}$ \\
5 & 50.6 & $\mathrm{C}$ & 42.9 & $\mathrm{C}$ & 41.7 & $\mathrm{C}$ \\
6 & 31.3 & $\mathrm{CH}_{2}$ & 37.5 & $\mathrm{CH}_{2}$ & 32.5 & $\mathrm{CH}_{2}$ \\
7 & 24.0 & $\mathrm{CH}_{2}$ & 23.8 & $\mathrm{CH}_{2}$ & 23.9 & $\mathrm{CH}_{2}$ \\
8 & 47.2 & $\mathrm{CH}$ & 48.5 & $\mathrm{CH}$ & 48.0 & $\mathrm{CH}$ \\
9 & 50.1 & $\mathrm{CH}_{3}$ & 42.4 & $\mathrm{CH}$ & 42.4 & $\mathrm{CH}$ \\
10 & 29.5 & $\mathrm{CH}_{2}$ & 44.4 & $\mathrm{CH}_{2}$ & 44.6 & $\mathrm{CH}_{2}$ \\
11 & 42.5 & $\mathrm{CH}_{2}$ & 224.3 & $\mathrm{C}$ & 224.1 & $\mathrm{C}$ \\
12 & 43.8 & $\mathrm{C}$ & 49.7 & $\mathrm{C}$ & 50.1 & $\mathrm{C}$ \\
13 & 38.1 & $\mathrm{CH}_{2}$ & 35.6 & $\mathrm{CH}_{2}$ & 38.5 & $\mathrm{CH}_{2}$ \\
14 & 47.0 & $\mathrm{CH}_{13}$ & 51.7 & $\mathrm{CH}_{2}$ & 46.0 & $\mathrm{CH}$ \\
15 & 18.9 & $\mathrm{CH}_{3}$ & 23.0 & $\mathrm{CH}_{3}$ & 23.0 & $\mathrm{CH}_{3}$ \\
16 & 21.4 & $\mathrm{CH}_{3}$ & 17.2 & $\mathrm{CH}_{3}$ & 17.3 & $\mathrm{CH}_{3}$ \\
17 & 147.4 & $\mathrm{C}$ & 147.0 & $\mathrm{C}$ & 147.2 & $\mathrm{C}$ \\
18 & 112.8 & $\mathrm{CH}_{2}$ & 113.3 & $\mathrm{CH}_{2}$ & 113.4 & $\mathrm{CH}_{2}$ \\
19 & 23.4 & $\mathrm{CH}_{3}$ & 25.8 & $\mathrm{CH}_{3}$ & 26.0 & $\mathrm{CH}_{3}$ \\
20 & 27.8 & $\mathrm{CH}_{3}$ & 12.0 & $\mathrm{CH}_{3}$ & 9.7 & $\mathrm{CH}_{3}$ \\
\hline
\end{tabular}

The relative configurations of the stereocenters of metabolite 1 were established by analysis of the key correlations displayed in the NOESY spectrum (Figure 3). The NOE enhancements of H-8/H-9, $\mathrm{H}-8 / \mathrm{H}_{3}-20$, and $\mathrm{H}-14 / \mathrm{H}_{3}-16$ provided evidence that $\mathrm{H}-14$ and $\mathrm{H}_{3}-16$ were cofacial, whereas $\mathrm{H}-8$, $\mathrm{H}-9$, and $\mathrm{H}_{3}-20$ were on the opposite side of the molecule, thus suggesting the trans fusion of the six- and seven-membered rings, as well as of the seven- and five-membered rings and determining the relative configurations of the chiral centers C-5, C-8, C-9, C-12, and C-14 as 5S*, $8 S^{*}, 9 S^{*}, 12 R^{*}, 14 S^{*}$, in accordance with previously reported dolastane derivatives isolated from the same algal specimens [3]. Taking into account that the ether bridge formation between $\mathrm{C}-1$ and $\mathrm{C}-4$ required the $c$ is orientation of the substituents at the $\alpha$ and $\alpha^{\prime}$ positions to the ether linkage, namely $\mathrm{H}-4$ and $\mathrm{H}_{3}-15$, in conjunction with the interactions of $\mathrm{H}-4$ with $\mathrm{H}_{2}-3, \mathrm{H}_{2}-6$, and $\mathrm{H}_{3}-20$, as well as of $\mathrm{H}-3 \alpha$ with $\mathrm{H}-6 \alpha$ observed in the NOESY spectrum, the relative configurations at $\mathrm{C}-1$ and $\mathrm{C}-4$ were determined as $1 R^{*}, 4 S^{*}$. The absence of a COSY correlation between $\mathrm{H}-3 \alpha$ and $\mathrm{H}-4$, indicating that the dihedral angle $\mathrm{H}-3 \alpha-\mathrm{C}-3-\mathrm{C}-4-\mathrm{H}-4$ was approaching $90^{\circ}$, further supported the proposed conformation.

Compound 2, obtained as a yellow oil, had the molecular formula $\mathrm{C}_{20} \mathrm{H}_{32} \mathrm{O}_{3}$, as calculated from the HRFABMS measurements and NMR data. The spectroscopic characteristics of $\mathbf{2}$ were rather similar to those of metabolite 1. Specifically, the ${ }^{1} \mathrm{H}$ NMR spectrum (Table 1), as in the case of $\mathbf{1}$, included signals for four singlet methyls $\left(\delta_{\mathrm{H}} 0.88,1.03,1.07\right.$, and 1.78), one exomethylene group $\left(\delta_{\mathrm{H}} 4.68\right.$ and 4.96$)$, and an oxygenated methine $\left(\delta_{\mathrm{H}} 3.19\right)$. The ${ }^{13} \mathrm{C}$ NMR spectrum (Table 2$)$ revealed 20 carbon signals, among which one carbonyl $\left(\delta_{\mathrm{C}} 224.3\right)$, two olefinic $\left(\delta_{\mathrm{C}} 113.3\right.$ and 147.0), and two oxygenated $\left(\delta_{\mathrm{C}} 72.3\right.$ and 78.2) carbons were evident. The absorption bands at 1728 and $3430 \mathrm{~cm}^{-1}$ observed in the IR spectrum, in conjunction with the molecular formula indicated the presence of a ketone moiety and two hydroxy 
groups in the molecule. The HMBC correlations of $\mathrm{C}-11$ with $\mathrm{H}-8, \mathrm{H}-9, \mathrm{H}_{2}-10$, and $\mathrm{H}_{3}-16$ fixed the position of the ketone functionality, whereas the correlations of $\mathrm{C}-1$ with $\mathrm{H}_{2}-2, \mathrm{H}-14$, and $\mathrm{H}_{3}-15$ and C-4 with $\mathrm{H}_{2}-3$ and $\mathrm{H}_{3}-20$ placed the two hydroxy groups at $\mathrm{C}-1$ and $\mathrm{C}-4$. The relative configurations of the chiral centers of 2 were determined on the basis of the key correlations observed in the NOESY spectrum. In particular, the NOE interactions of $\mathrm{H}-8 / \mathrm{H}-9, \mathrm{H}-8 / \mathrm{H}_{3}-20$, and $\mathrm{H}-14 / \mathrm{H}_{3}-16$ suggested the same relative configurations at C-5, C-8, C-9, C-12, and C-14 as in the case of $\mathbf{1}$, while the cross peaks of $\mathrm{H}-4 / \mathrm{H}-14$ and $\mathrm{H}_{3}-15 / \mathrm{H}_{3}-20$ established the relative configurations at $\mathrm{C}-1$ and $\mathrm{C}-4$ as $1 S^{*}, 4 S^{*}$.

Figure 3. Key NOESY correlations observed for compound 1.

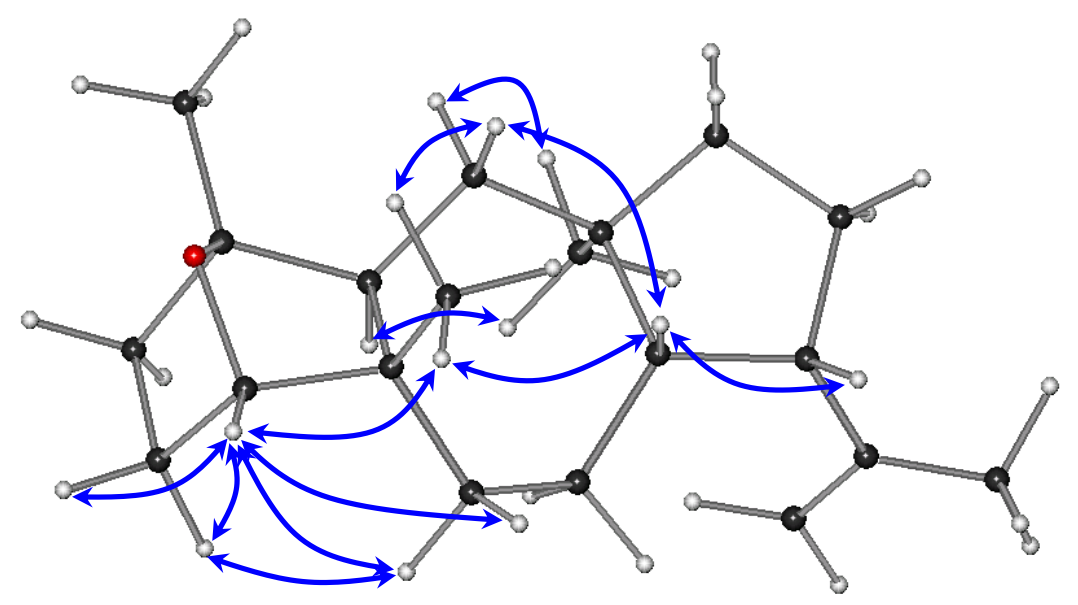

Compound 3 was isolated as a colorless oil. The structural elements displayed in the ${ }^{1} \mathrm{H}$ and ${ }^{13} \mathrm{C}$ NMR spectra of $\mathbf{3}$ closely resembled those of metabolite 2 . The ${ }^{1} \mathrm{H}$ NMR spectrum (Table 1) included signals for two aliphatic and two vinylic singlet methyls $\left(\delta_{\mathrm{H}} 0.84,1.07,1.63\right.$, and 1.82$)$, one exomethylene group $\left(\delta_{\mathrm{H}} 4.71\right.$ and 4.99), an olefinic methine $\left(\delta_{\mathrm{H}} 5.32\right)$, and an oxygenated proton $\left(\delta_{\mathrm{H}} 3.42\right)$, whereas the ${ }^{13} \mathrm{C}$ NMR spectrum (Table 2) revealed 20 carbon signals, among which a carbonyl $\left(\delta_{\mathrm{C}} 224.1\right)$, one oxygenated $\left(\delta_{\mathrm{C}} 74.9\right)$, and four olefinic $\left(\delta_{\mathrm{C}} 113.4,120.4,135.6\right.$, and 147.2) carbons were apparent. In agreement with the molecular formula $\mathrm{C}_{20} \mathrm{H}_{30} \mathrm{O}_{2}$, as deduced from the HRFABMS data, it was obvious that the difference between $\mathbf{2}$ and $\mathbf{3}$ was the absence of one hydroxy group and the formation of a second carbon-carbon double bond. The trisubstituted double bond was placed between C-1 and C-2 as indicated by the HMBC correlations of both $\mathrm{C}-4$ and $\mathrm{C}-15$ with $\mathrm{H}-2$. The relative configurations of the stereogenic centers of $\mathbf{3}$ were established by analysis of the key NOE enhancements observed, in accordance with those of 2 , as $4 S^{*}, 5 S^{*}, 8 S^{*}, 9 S^{*}, 12 R^{*}, 14 R^{*}$.

Reduction of metabolite 2 according to Molander et al. [13] yielded the 11-deoxo derivative of 2 , identical in all respects to $(1 S, 4 S, 8 S, 14 S)$-1,4-dihydroxy-17-dolastene [3]. Since the semisynthetic compound exhibited the same sign of optical rotation as the natural product previously isolated from the same algal collection [3], for which the absolute configuration was determined by application of Mosher's method, the absolute configuration of $\mathbf{2}$ was established as depicted. The absolute configurations of metabolites $\mathbf{1}$ and $\mathbf{3}$ were not determined due to the limited available amounts, but on the basis of biogenetic considerations they are expected to be the same.

Among the new dolastanes isolated in the present study, metabolite 2, which was obtained in adequate quantity, was evaluated for its cytotoxic activity against four human apoptosis-resistant (U373, 
A549, SKMEL28, OE21) and two human apoptosis-sensitive (PC3, LoVo) cancer cell lines, since previously isolated dolastanes had shown moderate cytotoxicity [3]. Furthermore, compound 2 was tested for its inhibitory effect on the hypoxia-inducible factor-1 (HIF-1). However, in both cases metabolite 2 exhibited no activity.

\section{Experimental Section}

\subsection{General Experimental Procedures}

Optical rotations were measured on a Perkin-Elmer model 341 polarimeter with a $1 \mathrm{dm}$ cell. UV spectra were obtained on a Shimadzu UV-160A spectrophotometer. IR spectra were obtained on a Paragon 500 Perkin-Elmer spectrometer. NMR spectra were recorded on Bruker AC 200 and Bruker DRX 400 spectrometers. Chemical shifts are given on a $\delta(\mathrm{ppm})$ scale using TMS as internal standard. The 2D experiments (HSQC, HMBC, COSY, NOESY) were performed using standard Bruker pulse sequences. High resolution FAB mass spectral data were provided by the University of Notre Dame, Department of Chemistry and Biochemistry, Notre Dame, IN, USA. Low resolution EI mass spectra were measured on a Hewlett Packard 5973 mass spectrometer. Column chromatography separations were performed with Kieselgel 60 (Merck). HPLC separations were conducted using a CECIL 1100 Series liquid chromatography pump equipped with a GBC LC-1240 refractive index detector, using the following columns: (i) Econoshpere Silica 10u (Alltech, $25 \mathrm{~cm} \times 10 \mathrm{~mm}$ ) and (ii) Chiralcel OD $10 \mu \mathrm{m}$ (Daicel Chemical Industries Ltd., Osaka, Japan, $25 \mathrm{~cm} \times 10 \mathrm{~mm}$ ). TLC were performed with Kieselgel $60 \mathrm{~F}_{254}$ (Merck aluminum support plates) and spots were detected after spraying with $15 \% \mathrm{H}_{2} \mathrm{SO}_{4}$ in $\mathrm{MeOH}$ reagent and heating at $100{ }^{\circ} \mathrm{C}$ for $1 \mathrm{~min}$. The lyophilization was carried out in a Freezone 4.5 freeze dry system (Labconco).

\subsection{Plant Material}

Specimens of Dilophus spiralis were collected by hand in Elafonissos island, south of Peloponnese, Greece, at a depth of 0.1-1 m, in April of 2004. A voucher specimen of the alga has been deposited at the Herbarium of the Department of Pharmacognosy and Chemistry of Natural Products, University of Athens (ATPH/MO/159).

\subsection{Extraction and Isolation}

Specimens of the freeze-dried alga (272 g) were exhaustively extracted with $\mathrm{CH}_{2} \mathrm{Cl}_{2}$ and subsequently with $\mathrm{MeOH}$ at room temperature. Evaporation of the solvents in vacuo afforded two dark green oily residues. The $\mathrm{CH}_{2} \mathrm{Cl}_{2}$ residue $(9.2 \mathrm{~g}$ ) was subjected to vacuum column chromatography on silica gel, using cyclohexane with increasing amounts of EtOAc, followed by EtOAc with increasing amounts of $\mathrm{MeOH}$ as the mobile phase, to yield fifteen fractions (A1-A15). Fraction A3 (20\% EtOAc in cyclohexane, $1.17 \mathrm{~g}$ ) was further fractionated by gravity column chromatography on silica gel, using cyclohexane with increasing amounts of EtOAc as the mobile phase, to afford twenty-one fractions (A3a-A3u). Fraction A3b (1\% EtOAc in cyclohexane, $355.7 \mathrm{mg}$ ) was subjected to gravity column chromatography on silica gel, using cyclohexane with increasing amounts of $\mathrm{CH}_{2} \mathrm{Cl}_{2}$, followed by $\mathrm{CH}_{2} \mathrm{Cl}_{2}$ with increasing amounts of EtOAc as the mobile phase, to yield eleven fractions (A3b1-A3b11). 
Fraction A3b8 (100\% $\mathrm{CH}_{2} \mathrm{Cl}_{2}, 55.6 \mathrm{mg}$ ) was purified by normal phase HPLC, using cyclohexane/EtOAc (99:1) as eluant, to afford isopachydictyol A (12.4 mg) and pachydictyol A (21.4 mg). Fractions A3c (1\% EtOAc in cyclohexane, $162.9 \mathrm{mg}$ ) and A3d (1\% EtOAc in cyclohexane, $55.3 \mathrm{mg}$ ) were separately purified by normal phase HPLC, using $n$-hexane/EtOAc (98:2) and subsequently $n$-hexane/ $i$-propanol (99.5:0.5) as eluant, to yield 1 (0.6 mg), isopachydictyol A (7.6 mg), and pachydictyol A (13.2 mg). Fraction A4 (30\% EtOAc in cyclohexane, $3.58 \mathrm{~g}$ ) was further fractionated by vacuum column chromatography on silica gel, using cyclohexane with increasing amounts of EtOAc, followed by EtOAc with increasing amounts of $\mathrm{MeOH}$ as the mobile phase, to afford nine fractions (A4a-A4i). Fraction A4b (10\% EtOAc in cyclohexane, $46.1 \mathrm{mg}$ ) was purified by normal phase HPLC, using cyclohexane/EtOAc (98:2) as eluant, to yield dictyoxide $(0.4 \mathrm{mg})$, isopachydictyol A $(0.5 \mathrm{mg})$, and pachydictyol A (1.5 mg). Fraction A4c (20\% EtOAc in cyclohexane, $812.3 \mathrm{mg}$ ) was subjected to gravity column chromatography on silica gel, using cyclohexane with increasing amounts of EtOAc, followed by EtOAc with increasing amounts of $\mathrm{MeOH}$ as the mobile phase, to afford twenty-three fractions (A4c1-A4c23). Fractions A4c2 (1\% EtOAc in cyclohexane, $174.3 \mathrm{mg})$ and A4c3 (1\% EtOAc in cyclohexane, $129.8 \mathrm{mg}$ ) were separately purified by normal phase HPLC, using $n$-hexane/EtOAc (97:3) and subsequently $n$-hexane/ $i$-propanol (99.5:0.5) as eluant, to yield dictyoxide (4.1 $\mathrm{mg}$ ), isopachydictyol A (18.4 mg), and pachydictyol A (17.6 mg). Fractions A4c15 (12\% EtOAc in cyclohexane, $138.5 \mathrm{mg})$, A4c16 (20\% EtOAc in cyclohexane, $13.3 \mathrm{mg}$ ), and A4c17 (20\% EtOAc in cyclohexane, $24.7 \mathrm{mg}$ ) were separately purified by normal phase HPLC, using cyclohexane/EtOAc (90:10 and 92:8) as eluant, to afford $\mathbf{3}(0.7 \mathrm{mg})$. Fraction A10 (90\% EtOAc in cyclohexane, $38.9 \mathrm{mg}$ ) was identified as 2. The $\mathrm{MeOH}$ residue ( $32.8 \mathrm{~g}$ ) was subjected to vacuum column chromatography on silica gel, using cyclohexane with increasing amounts of EtOAc, followed by EtOAc with increasing amounts of $\mathrm{MeOH}$ as the mobile phase, to yield fourteen fractions (B1-B14). Fraction B1 (10\% EtOAc in cyclohexane, $51.0 \mathrm{mg}$ ) was repeatedly purified by normal phase HPLC, using $n$-hexane (100\%) as eluant, to afford dictytriene B (0.9 mg). Fraction B3 (20\% EtOAc in cyclohexane, $361.0 \mathrm{mg}$ ) was repeatedly purified by normal phase HPLC, using cyclohexane/EtOAc (90:10) as eluant, to yield dictyol E (3.0 mg). Fraction B12 (35\% $\mathrm{MeOH}$ in EtOAc, $69.3 \mathrm{mg}$ ) was identified as 2.

\subsection{1. $(1 R, 4 S, 8 S, 14 S)$-1,4-Epoxy-17-dolastene (1)}

Colorless oil; $[\alpha]_{\mathrm{D}}^{20}+60.0\left(c 0.04, \mathrm{CHCl}_{3}\right) ; \mathrm{UV}\left(\mathrm{CHCl}_{3}\right) \lambda_{\max }(\log \varepsilon) 242.5(2.03) \mathrm{nm}$; IR (thin film) $\nu_{\max } 2951,2846,1275,908 \mathrm{~cm}^{-1}$; ${ }^{1} \mathrm{H}$ NMR data, see Table $1 ;{ }^{13} \mathrm{C}$ NMR data, see Table 2; EIMS $70 \mathrm{eV}$ m/z (rel. int. \%) 288 (35), 273 (73), 255 (18), 245 (39), 227 (24), 203 (28), 187 (30), 175 (44), 161 (52), 147 (74), 135 (94), 121 (100), 107 (99), 93 (89), 79 (73), 67 (55), 55 (53); HRFABMS m/z 288.2459 $[\mathrm{M}]^{+}$(calcd. for $\mathrm{C}_{20} \mathrm{H}_{32} \mathrm{O}, 288.2453$ ).

\subsection{2. (1S,4S,8S,14S)-1,4-Dihydroxy-11-oxo-17-dolastene (2)}

Yellow oil; $[\alpha]_{\mathrm{D}}^{20}-32.0\left(c 0.15, \mathrm{CHCl}_{3}\right)$; UV $\left(\mathrm{CHCl}_{3}\right) \lambda_{\max }(\log \varepsilon) 242.0(2.73) \mathrm{nm}$; IR (thin film) $v_{\max }$ 3430, 2936, 1728, $1289 \mathrm{~cm}^{-1} ;{ }^{1} \mathrm{H}$ NMR data, see Table $1 ;{ }^{13} \mathrm{C}$ NMR data, see Table 2; EIMS $70 \mathrm{eV} \mathrm{m} / \mathrm{z}$ (rel. int. \%) 320 (17), 302 (10), 287 (18), 251 (27), 234 (35), 223 (68), 205 (83), 187 (49), 177 (41), 163

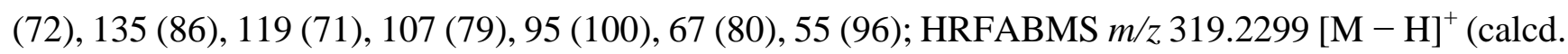
for $\mathrm{C}_{20} \mathrm{H}_{31} \mathrm{O}_{3}, 319.2273$ ). 


\subsection{3. (4S,8S,14R)-4-Hydroxy-11-oxo-1,17-dolastadiene (3)}

Colorless oil; $[\alpha]_{\mathrm{D}}^{20}-75.8\left(c 0.03, \mathrm{CHCl}_{3}\right) ; \mathrm{UV}\left(\mathrm{CHCl}_{3}\right) \lambda_{\max }(\log \varepsilon) 242.5(2.40) \mathrm{nm}$; IR (thin film) $v_{\max } 3422,2930,1733,1275 \mathrm{~cm}^{-1} ;{ }^{1} \mathrm{H}$ NMR data, see Table $1 ;{ }^{13} \mathrm{C}$ NMR data, see Table 2; EIMS $70 \mathrm{eV}$ m/z (rel. int. \%) 302 (11), 284 (54), 269 (19), 241 (13), 187 (27), 173 (24), 163 (37), 159 (37), 145 (40), 135 (92), 121 (65), 105 (100), 91 (73), 79 (49), 67 (31), 55 (26); HRFABMS m/z 303.2327 [M + H] $]^{+}$ (calcd. for $\mathrm{C}_{20} \mathrm{H}_{31} \mathrm{O}_{2}, 303.2324$ ).

\subsection{Reduction of 2}

Compound $2(20.0 \mathrm{mg})$ was treated with hydrazine hydrate $(100 \mu \mathrm{L})$ and $\mathrm{K}_{2} \mathrm{CO}_{3}(80 \mathrm{mg})$ in diethylene glycol $(3 \mathrm{~mL})$ and left under constant stirring at $150{ }^{\circ} \mathrm{C}$ for $1 \mathrm{~h}$. Subsequently, the condenser was removed and the temperature was increased to $200{ }^{\circ} \mathrm{C}$. After the excess of hydrazine and water had boiled off, the condenser was replaced and the temperature was maintained at $205{ }^{\circ} \mathrm{C}$ for $1.5 \mathrm{~h}$. After cooling, the mixture was partitioned between $\mathrm{CH}_{2} \mathrm{Cl}_{2}$ and $10 \% \mathrm{HCl}$. The organic layer was washed again with $10 \% \mathrm{HCl}$ and subsequently with $\mathrm{H}_{2} \mathrm{O}$ and saturated $\mathrm{NaHCO}_{3}$, dried over anhydrous $\mathrm{MgSO}_{4}$ and filtered. After evaporation of the organic layer in vacuo, the residue was purified by normal phase HPLC, using cyclohexane/EtOAc (50:50) as eluant, to afford the 11-deoxo derivative of 2 ( $4.7 \mathrm{mg})$.

\section{Conclusions}

A chemical investigation of the organic extracts of the brown alga D. spiralis led to the isolation of three new diterpenes (1-3) featuring the relatively rare dolastane skeleton isolated exclusively from marine sources and five previously reported perhydroazulenes. Their structures and relative configurations were determined on the basis of their spectroscopic data (NMR, MS, IR). The absolute configuration of $\mathbf{2}$ was determined on the basis of its chemical conversion to a dolastane of known configuration. Metabolite $\mathbf{2}$ was evaluated for but did not display noteworthy cytotoxic activity against six cancer cell lines or inhibitory effect on the hypoxia-inducible factor-1 (HIF-1).

\section{Acknowledgments}

This study was partially supported by a "Kapodistrias" grant from the University of Athens. The authors thank R. Kiss (Institut de Pharmacie, Université Libre de Bruxelles, Belgium) and D. Nagle (School of Pharmacy, University of Mississippi, USA) for the activity evaluation of compound 2.

\section{References}

1. Blunt, J.W.; Copp, B.R.; Keyzers, R.A.; Munro, M.H.G.; Prinsep, M.R. Marine natural products. Nat. Prod. Rep. 2012, 29, 144-222.

2. MarinLit Database. Available online: http://www.chem.canterbury.ac.nz/marinlit/marinlit.shtml (accessed on 13 December 2012). 
3. Ioannou, E.; Quesada, A.; Vagias, C.; Roussis, V. Dolastanes from the brown alga Dilophus spiralis: Absolute stereochemistry and evaluation of cytotoxicity. Tetrahedron 2008, 64, 3975-3979.

4. Ioannou, E.; Zervou, M.; Ismail, A.; Ktari, L.; Vagias, C.; Roussis, V. 2,6-Cyclo-Xenicanes from the brown algae Dilophus fasciola and Dilophus spiralis. Tetrahedron 2009, 65, 10565-10572.

5. Ioannou, E.; Quesada, A.; Rahman, M.M.; Gibbons, S.; Vagias, C.; Roussis, V. Dolabellanes with antibacterial activity from the brown alga Dilophus spiralis. J. Nat. Prod. 2011, 74, 213-222.

6. Ioannou, E.; Vagias, C.; Roussis, V. Dilospiranes A and B: Diterpenes featuring novel carbocyclic units from the brown alga Dilophus spiralis. Tetrahedron Lett. 2011, 52, 3054-3056.

7. Ioannou, E.; Quesada, A.; Rahman, M.M.; Gibbons, S.; Vagias, C.; Roussis, V. Structures and antibacterial activities of minor dolabellanes from the brown alga Dilophus spiralis. Eur. J. Org. Chem. 2012, 2012, 5177-5186.

8. Enoki, N.; Ishida, R.; Urano, S.; Ochi, M.; Tokoroyama, T.; Matsumoto, T. New hydroazulenoid diterpenes from the marine alga Dictyota dichotoma. Chem. Lett. 1982, 11, 1837-1840.

9. Amico, V.; Oriente, G.; Piattelli, M.; Tringali, C. Dictyoxide, a new diterpene from the brown alga Dilophus ligulatus. Phytochemistry 1979, 18, 1895-1897.

10. Hirschfeld, D.R.; Fenical, W.; Lin, G.H.Y.; Wing, R.M.; Radlick, P.; Sims, J.J. Marine natural products. VIII. Pachydictyol A, an exceptional diterpene alcohol from the brown alga Pachydictyon coriaceum. J. Am. Chem. Soc. 1973, 95, 4049-4050.

11. Durán, R.; Zubía, E.; Ortega, M.J.; Salvá, J. New diterpenoids from the alga Dictyota dichotoma. Tetrahedron 1997, 53, 8675-8688.

12. Danise, B.; Minale, L.; Riccio, R.; Amico, V.; Oriente, G.; Piattelli, M.; Tringali, C.; Fattorusso, E.; Magno, S.; Mayol, L. Further perhydroazulene diterpenes from marine organisms. Experientia 1977, 33, 413-415.

13. Molander, G.A.; Quirmbach, M.S.; Silva, L.F.; Spencer, K.C.; Balsells, J. Toward the total synthesis of variecolin. Org. Lett. 2001, 3, 2257-2260.

Samples Availability: Available from the authors.

(C) 2013 by the authors; licensee MDPI, Basel, Switzerland. This article is an open access article distributed under the terms and conditions of the Creative Commons Attribution license (http://creativecommons.org/licenses/by/3.0/). 